\title{
Fitzgerald Trait
}

\author{
DEFICIENCY OF A HITHERTO UNRECOGNIZED AGENT, \\ FITZGERALD FACTOR, PARTICIPATING IN SURFACE- \\ MEDIATED REACTIONS OF CLOTTING, FIBRINOLYSIS, \\ GENERATION OF KININS, AND THE PROPERTY OF DILUTED \\ PLASMA ENHANCING VASCULAR PERMEABILITY (PF/DIL)
}

\author{
Hmehuxo Saito, Oscar D. Ratnoff, Robert Waldmann, and \\ Joseph P. ABraham \\ From the Department of Medicine, Case Western Reserve University \\ School of Medicine and University Hospitals of Cleveland, Cleveland, \\ Ohio 44106, and from the Department of Medicine, Henry Ford Hospital, \\ Detroit, Michigan 48202
}

A в STRACT The prolonged partial thromboplastin time observed in the plasma of a 71-yr-old asymptomatic man was related to the deficiency of a hitherto unrecognized agent. The patient's plasma also exhibited impaired surface-mediated fibrinolysis and esterolytic activity and impaired generation of kinins and of the property enhancing vascular permeability designated PF/Dil. The patient's plasma contained normal amounts of all known clotting factors except Fletcher factor (a plasma prekallikrein) which was present at a concentration of $10-15 \%$ of pooled normal plasma. Fletcher trait plasma, however, contained normal amounts of the agent missing from the patient's plasma and corrected the defects in clotting, fibrinolysis, and vascular permeability. Fletcher trait plasma was less effective in correcting generation of kinins and esterolytic activity, presumably because of the patient's partial deficiency of prekallikrein. The site of action of the factor deficient in the patient's plasma appeared to be subsequent to the activation of Hageman factor and plasma prekallikrein. A fraction of normal plasma, devoid of other clotting factors, corrected the defect in clotting in the patient's plasma; a similar fraction of the patient's plasma did not correct this abnormality. No evidence yet exists pointing to the familial nature of the patient's

Presented at the International Conference on Chemistry and Biology of the Kallikrein-Kinin System in Health and Disease, Reston, Va., 22 October 1974, and at the American Society of Hematology, 11 December 1974.

Dr. Ratnoff is a career investigator of the American Heart Association.

Received for publication 19 November 1974 and in revised form 2 January 1975. defect. Tentatively, the patient's disorder may be referred to by his surname as Fitzgerald trait, and the agent apparently deficient in his plasma as Fitzgerald factor.

\section{INTRODUCTION}

Activated Hageman factor ( $\mathrm{HF},{ }^{1}$ Factor XII) participates in the surface-mediated reactions of clotting, esterase- and kinin-generation, fibrinolysis, and enhancement of vascular permeability. These properties of $\mathrm{HF}$ are mediated or intensified by Fletcher factor, a plasma prekallikrein deficient in Fletcher trait $(1,2)$. In early experiments, crude activated $\mathrm{HF}$ appeared to activate plasma thromboplastin antecedent (PTA, Factor XI) enzymatically (3). When more purified systems became available, activation of PTA by activated HF was no longer demonstrable (4). Although activated Fletcher factor (a plasma kallikrein) is needed for optimal activation of PTA (2), incubation of a mixture of $\mathrm{HF}$, PTA, prekallikrein, and kaolin still did not result in activation of PTA (4). These observations suggest that the activation of PTA requires the presence of one or more additional agents.

This report describes studies in an asymptomatic 71yr-old man in whom a defect in the intrinsic pathway of thrombin formation was detected by chance (5). His plasma was apparently deficient in a hitherto unrecog-

\footnotetext{
${ }^{1}$ Abbreviations used in this paper: AHF, antihemophilic factor; $\mathrm{HBr}$, hexadimethrine bromide; HF, Hageman factor; PF/Dil, property of diluted plasma enhancing vascular permeability; PTA, plasma thromboplastin antecedent; PTT, partial thromboplastin time; TAME, p-toluenesulfonyl-L-arginine methyl ester.
} 
nized factor needed for expression of the functions of activated HF (6). With his permission we have named his disorder Fitzgerald trait, and the agent functionally deficient in his plasma, Fitzgerald factor. A similar patient, described by Colman, Bagdasarian, Talamo, and Kaplan (7) while our studies were in progress, appears to have an identical defect.

\section{METHODS}

Unless otherwise noted, human citrated plasma, animal plasmas, purified clotting factors, and reagents were prepared or obtained as described earlier (8-11). Fletcher trait plasma was kindly supplied by Dr. C. Abildgaard, University of California, Davis.

The effect of Celite adsorption of normal plasma upon various clotting factor activities was studied using Celite 512 (diatomaceous earth, a gift of Johns-Manville Products Corp., Celite division, New York) as described by Nossel (12).

A crude fraction that corrected the patient's clotting defect was separated from normal or HF-deficient plasma, adsorbed for $10 \mathrm{~min}$ at room temperature with $1 / 10 \mathrm{vol}$ of alumina $\mathrm{C}_{\boldsymbol{\gamma}}$ gel (Calbiochem, San Diego, Calif.). The adsorbed plasma was mixed with $1 / 100$ vol of $0.01 \mathrm{M}$ sodium EDTA and $5 \mathrm{mg}$ of hexadimethrine bromide ( $\mathrm{HBr}$ ) (Aldrich Chem. Co. Inc., Milwaukee, Wis.) per $\mathrm{ml}$ and was dialyzed against $0.1 \mathrm{M}$ sodium chloride in $0.025 \mathrm{M}$ Tris-chloride buffer ( $\mathrm{pH} 8.0$ ) containing $0.0001 \mathrm{M}$ EDTA and $0.05 \mathrm{mg}$ $\mathrm{HBr}$ per ml. This material was chromatographed on a column of QAE-Sephadex A-50 (Pharmacia Fine Chemicals, Inc., Piscataway, N. J.), as described earlier (8), except that the starting buffer contained $0.1 \mathrm{M}$ sodium chloride and elution was via a linear gradient to $0.5 \mathrm{M} \mathrm{NaCl}$ in the same buffer. The molecular weight of fractions with correcting activity was examined by filtering the concentrated, pooled active fractions from a QAE-Sephadex A-50 column through a column of Sephadex G-150 (Pharmacia Fine Chemicals Inc.) equilibrated with a barbital-saline buffer (8). In one experiment with HF-deficient plasma, fractions with corrective activity were concentrated, dialyzed against $0.05 \mathrm{M}$ sodium acetate buffer ( $\mathrm{pH}$ 5.2) containing $0.15 \mathrm{M}$ sodium chloride and $0.0001 \mathrm{M}$ EDTA, and chromatographed upon SP-Sephadex C-50 (Pharmacia Fine Chemicals Inc.), as described earlier (8).

Batch preparation of the corrective fraction of normal plasma was performed as follows. 2-ml plasma was adsorbed with alumina $\mathrm{C}_{\boldsymbol{\gamma}}$ gel, mixed with EDTA and $\mathrm{HBr}$, and dialyzed against $0.1 \mathrm{M}$ sodium chloride in a Tris-chlorideEDTA-HBr buffer as described above. The dialyzed plasma was mixed for $10 \mathrm{~min}$ at room temperature with an equal volume of QAE-Sephadex A-50, equilibrated with the same buffer in a $12 \times 75-\mathrm{mm}$ polystyrene tube. After centrifugation, the supernatant plasma was discarded and the precipitate was washed repeatedly with $10-\mathrm{ml}$ portions of buffer until the washings no longer formed a visible precipitate upon addition of an equal volume of $10 \%$ trichloroacetic acid. The washed QAE-Sephadex was then eluted twice for $10 \mathrm{~min}$ with $2-\mathrm{ml}$ portions of $0.5 \mathrm{M}$ sodium chloride in a Tris-chloride-EDTA-HBr buffer; each eluate was diluted and assayed for Fitzgerald factor activity. The patient's plasma was fractionated in the same way.

Procoagulant assays for various clotting factors (8), immunologic assays for HF (13) and AHF (Factor VIII) (14), kaolin-activated plasma esterolytic activity for $p$ toluenesulfonyl-L-arginine methyl ester (TAME) (15), kaolin-induced fibrinolytic activity (10), antiplasmin (10), Cì inactivator titer (16), and vascular permeability (17) were assayed as described earlier. Immunodiffusion was performed in a $0.9 \%$ agarose gel in a $0.05 \mathrm{M}$ barbital buffer ( $\mathrm{pH}$ 8.6) for 2 days at room temperature. A functional assay for the patient's deficient factor, based upon the kaolin-activated partial thromboplastin time (PTT) was devised. A volume of $0.1 \mathrm{ml}$ each of the test sample, suitably diluted in barbital-saline buffer, a mixture of kaolin (10 $\mathrm{mg} / \mathrm{ml})$ and phospholipid $(0.1 \%$ in saline, Centrolex "O," the gift of Central Soya Co., Inc., Chicago, Ill.), and the patient's plasma were incubated together for $1 \mathrm{~min}$ at $37^{\circ} \mathrm{C}$ in a $10 \times 75-\mathrm{mm}$ glass tube; studies performed subsequent to those in the present report suggest that a preliminary period of incubation of $8 \mathrm{~min}$ is superior to a 1-min period. The mixture was recalcified with $0.1 \mathrm{ml} 0.025 \mathrm{M}$ calcium chloride, and the clotting time was measured. The clotting time was converted to percentage activity by comparison with a calibration curve prepared by assaying serial dilutions of a standard pool of normal plasma (14); a linear relationship existed between the logarithm of the clotting time and the logarithm of $1 / 20$ to $1 / 200$ dilutions of the pooled plasma.

The effect upon the PTT of the patient's plasma by the addition of trypsin-activated PTA, kaolin-activated HF, and kallikrein (10), and the effect upon the Thrombotest time of incubating plasma with kaolin at $0^{\circ} \mathrm{C}$ were studied as described (18).

Generation of kinin-like activity was tested on the estrous rat uterus, adding atropine sulfate $(1 \mu \mathrm{g}$ per $\mathrm{ml})$ to the deJalon's solution (19). In some experiments, kinin generation was estimated from the duration of delay between addition of the sample and the onset of contraction, an inverse function of the concentration of kinins (20). The effect of addition of ellagic acid or HF-fragments upon kinin generation was tested as described in Table II. The effect of plasma kallikrein upon kinin generation was tested in a mixture of $0.025 \mathrm{ml}$ kallikrein $(68 \mu \mathrm{mol} \mathrm{MeOH}$ released/ml per h, specific activity $755 \mu \mathrm{mol} \mathrm{MeOH} / \mathrm{mg}$ protein per $\mathrm{h}$ ), $0.05 \mathrm{ml}$ test plasma, $0.05 \mathrm{ml} 0.01 \mathrm{M} 0$-phenanthroline (Fisher Scientific Co., Inc., Pittsburgh, $\mathrm{Pa}$.), and $0.35 \mathrm{ml}$ barbital-saline buffer $(\mathrm{pH} 7.4)$ at $37^{\circ} \mathrm{C}$ in 12 $\times 75-\mathrm{mm}$ polystyrene tubes, testing samples for kinin-like activity. Kininogen in boiled plasma was measured as described by Diniz and Carvalho (21). Kinase was estimated by a modification of an earlier technique (22), incubating $5 \mu \mathrm{g}$ of bradykinin (the gift of Sandoz Pharmaceuticals, Hanover, N. J.) in $0.05 \mathrm{ml}$ barbital-saline buffer with 0.1 $\mathrm{ml}$ of the test plasma and $1.8 \mathrm{ml}$ of the same buffer in $12 \times 75-\mathrm{mm}$ polystyrene tubes at $37^{\circ} \mathrm{C}$. At intervals, $0.1-\mathrm{ml}$ portions were added to a similar polystyrene tube containing $0.2 \mathrm{ml}$ of $0.001 \mathrm{M} o$-phenanthroline and $1.6 \mathrm{ml}$ of buffer and were tested immediately for kinin-like activity.

\section{RESULTS}

Studies on the clotting defect in Fitzgerald trait. The kaolin-activated PTT of the patient's plasma was abnormally long (> $500 \mathrm{~s}$; control, $54 \mathrm{~s}$ ), whereas the one-stage prothrombin time was normal, localizing the functional defect to the initial steps of the intrinsic pathway. Functional concentrations of HF, PTA, Christmas factor (Factor IX), and antihemophilic factor (AHF) were normal, while that of Fletcher factor was $10-15 \%$ that of pooled normal plasma (5). Immunologic assays 
TABLE I

Effect of Kaolin-Activated HF, Kallikrein, and Activated PTA upon

Fitzgerald Trait Plasma

\begin{tabular}{lccccc}
\hline & \multicolumn{5}{c}{ Clotting time } \\
\cline { 2 - 6 } & $\begin{array}{c}\text { Fitzgerald } \\
\text { trait }\end{array}$ & $\begin{array}{c}\text { Hageman } \\
\text { trait }\end{array}$ & $\begin{array}{c}\text { Fletcher } \\
\text { trait }\end{array}$ & $\begin{array}{c}\text { PTA } \\
\text { deficient }\end{array}$ & $\begin{array}{c}\text { Christmas } \\
\text { disease }\end{array}$ \\
\hline & $s$ & $s$ & $s$ & $s$ & $s$ \\
PTT* & 237 & 59 & 62 & $>300$ & - \\
$\quad$ Plus kaolin-activated HF & $>300$ & $>300$ & 230 & $>300$ & - \\
$\quad$ Plus kaolin-albumin & & & & & \\
Kaolin-activated PTT $\ddagger$ & 234 & 213 & 75 & 151 & - \\
$\quad \begin{array}{l}\text { Plus kallikrein } \\
\text { Plus buffer }\end{array}$ & $>300$ & $>300$ & 226 & 204 & - \\
PTT\& & 75 & 77 & 76 & 75 & $>300$ \\
$\quad$ Plus activated PTA & $>300$ & $>300$ & $>300$ & $>300$ & $>300$ \\
Plus buffer & & & & & \\
\hline
\end{tabular}

* $0.4 \mathrm{ml} \mathrm{HF}(1.25 \mathrm{U} / \mathrm{ml}$, specific activity: $50 \mathrm{U} / \mathrm{mg}$ protein) in bovine crystalline albumin $(1 \mathrm{mg} / \mathrm{ml})$ or bovine albumin was shaken with $0.1 \mathrm{ml}$ kaolin $(50 \mathrm{mg} / \mathrm{ml})$ for $10 \mathrm{~min}$ at $37^{\circ} \mathrm{C}$ in a $12 \times 75-\mathrm{mm}$ polystyrene tube. $0.1 \mathrm{ml}$ kaolin-activated $\mathrm{HF}$ or kaolin-albumin was then added to $0.1 \mathrm{ml}$ Centrolex " 0 " and $0.1 \mathrm{ml}$ test plasma in a $10 \times 75-\mathrm{mm}$ glass tube. After $1 \mathrm{~min}$ incubation at $37^{\circ} \mathrm{C}, 0.1 \mathrm{ml} 0.025 \mathrm{M} \mathrm{CaCl}_{2}$ was added and the clotting time was determined. $\ddagger 0.1 \mathrm{ml}$ plasma kallikrein $(68 \mu \mathrm{mol} \mathrm{MeOH}$ released $/ \mathrm{ml}$ per $\mathrm{h}$, specific activity: $755 \mu \mathrm{mol}$ $\mathrm{MeOH} / \mathrm{mg}$ protein/hour) or barbital-saline buffer was added to $0.1 \mathrm{ml}$ test plasma and 0.1 $\mathrm{ml}$ kaolin-Centrolex " 0 " in a $10 \times 75$ - $\mathrm{mm}$ glass tube. After $1 \mathrm{~min}$ incubation at $37^{\circ} \mathrm{C}, 0.1 \mathrm{ml}$ $0.025 \mathrm{M} \mathrm{CaCl}_{2}$ was added and the clotting time was measured.

$\S 0.1 \mathrm{ml}$ trypsin-activated PTA or barbital-saline buffer was added to $0.1 \mathrm{ml}$ test plasma and $0.1 \mathrm{ml}$ Centrolex " 0 " in a $10 \times 75-\mathrm{mm}$ polystyrene tube. After $1 \mathrm{~min}$ incubation at $37^{\circ} \mathrm{C}$, $0.1 \mathrm{ml} 0.025 \mathrm{M} \mathrm{CaCl}_{2}$ was added and the clotting time was determined.

of $\mathrm{HF}$ and $\mathrm{AHF}$ were in agreement with these data. On immunodiffusion the concentration of Fletcher factor appeared to be diminished. Normal plasma, or plasmas deficient in HF, PTA, or Fletcher factor, at a concentration of $5 \%$, shortened the kaolin-activated PTT from $>500$ to $94-106 \mathrm{~s}$, thus demonstrating the defect was not due to an inhibitor; killer whale plasma, functionally deficient in $\mathrm{HF}$ and Fletcher factor, had approximately $65 \%$ of the corrective activity of pooled normal human plasma, while that of chickens and Muscovy ducks had less than $5 \%$. Unlike Fletcher trait plasma (1), the PTT of the patient's plasma was not significantly shortened by prolonged incubation with kaolin.

Functional activity of $\mathrm{C} \overline{1}$ inactivator in the patient's plasma was $8.5 \mathrm{U} / \mathrm{ml}$ (normal range: 6-12 U/ml).

Addition of activated PTA shortened the PTT of the patient's plasma, PTA-deficient plasma, or HFdeficient plasma to the same degree, from $>300$ to $75 \mathrm{~s}$, while addition of kaolin-activated $\mathrm{HF}$ or of a plasma kallikrein (i.e., activated Fletcher factor) was without appreciable effect (Table I), as if the patient's defect were at a step after activation of $\mathrm{HF}$ and Fletcher factor but before participation of activated PTA.

The agent in normal plasma correcting the patient's clotting defect was stable at $-70^{\circ} \mathrm{C}$ for at least $2 \mathrm{yr}$, and it lost only $20 \%$ activity after heating of plasma at $56^{\circ} \mathrm{C}$ for $30 \mathrm{~min}$. It was not significantly adsorbed from oxalated plasma by tricalcium phosphate $(10 \mathrm{mg} / \mathrm{ml})$ or from citrated plasma by alumina $\mathrm{C} \gamma$ gel. It was not significantly removed by small amounts of Celite $(1 \sim 2$ $\mathrm{mg} / \mathrm{ml}$ plasma), whereas most of PTA and Fletcher factor activity was adsorbed under these conditions (Fig. 1). When normal plasma was adsorbed with $5 \mathrm{mg}$ Celite 512 per $\mathrm{ml}$ plasma, and the supernatant plasma was incubated at $37^{\circ} \mathrm{C}$ for $18 \mathrm{~h}$, it contained approximately $50 \%$ of the factor correcting the patient's defect and $70 \%$ of $\mathrm{HF}$ activity, but almost no PTA and Fletcher factor activity. It was completely removed from plasma by Celite at a concentration of $40 \mathrm{mg} / \mathrm{ml}$ and could then be partially eluted by $10 \%$ sodium chloride in $0.05 \mathrm{M}$ Tris-chloride buffer ( $\mathrm{pH} 8.0$ ). It was present in normal serum and in the fraction of plasma soluble at $20 \%$ and insoluble at $60 \%$ saturation with neutral ammonium sulfate. Unlike PTA, Fletcher factor and the precursor of $\mathrm{HF}$-cofactor (an agent needed for surface-mediated activation of plasminogen [23]), the corrective agent was adsorbed from normal or HFdeficient plasma onto columns of QAE-Sephadex A-50, an anionic resin, from which it could be eluted at an ionic strength slightly higher than that releasing $\mathrm{HF}$; 
TABLE II

Effect of Addition of Ellagic Acid, HF Fragments, and Kallikrein upon

Kinin Generation

\begin{tabular}{lc}
\hline \multicolumn{1}{c}{ Sample } & Kinin activity \\
\hline & $\begin{array}{c}\text { nanogram bradykinin equivalent } \\
\text { per } 0.1 \text { ml sample }\end{array}$ \\
Normal + ellagic acid* & 11.6 \\
HF deficient + ellagic acid & 0 \\
Fletcher trait + ellagic acid & 0 \\
Fitzgerald trait + ellagic acid & 0 \\
Fitzgerald trait + HF deficient + ellagic acid & 6.0 \\
Fitzgerald trait + Fletcher trait + ellagic acid & 2.3 \\
Fletcher trait + HF fragments $\ddagger$ & 0 \\
Fitzgerald trait + HF fragments & 0 \\
Fletcher trait + Fitzgerald trait + HF fragments & 5.0 \\
Fletcher trait + kallikrein§ & 3.6 \\
Fitzgerald trait + kallikrein & 0 \\
Fitzgerald trait + Fletcher trait + kallikrein & 2.8 \\
Fitzgerald trait + buffer + kallikrein & 0
\end{tabular}

* $0.05 \mathrm{ml}$ test plasma was incubated with $0.05 \mathrm{ml} 100 \mu \mathrm{M}$ ellagic acid, $0.05 \mathrm{ml} 0.01$ $\mathrm{M} o$-phenanthroline, and $0.35 \mathrm{ml}$ barbital-saline buffer $\left(\mathrm{pH} 7.4\right.$ ) at $37^{\circ} \mathrm{C}$ in a $12 \times 75-\mathrm{mm}$ polystyrene tube. After $12 \mathrm{~min}$, suitable portions were tested on a uterus muscle for kinin activity in comparison with a bradykinin standard, expressing the results as nanogram bradykinin equivalent generated per $0.1 \mathrm{ml}$ of the sample. $\ddagger 0.05 \mathrm{ml}$ test plasma was incubated with $0.015 \mathrm{ml} \mathrm{HF}$ fragments $(25 \mu \mathrm{g}$ protein $/ \mathrm{ml})$, $0.05 \mathrm{ml} 0.01 \mathrm{M} o$-phenanthroline, and $0.35 \mathrm{ml}$ barbital-saline buffer at $37^{\circ} \mathrm{C}$ in $12 \times 75-\mathrm{mm}$ polystyrene tubes. After $2 \mathrm{~min}$, suitable samples were tested as described above.

$\S 0.05 \mathrm{ml}$ test plasma was incubated with $0.025 \mathrm{ml}$ plasma kallikrein (68 $\mu \mathrm{mol}$ $\mathrm{MeOH}$ released $/ \mathrm{ml}$ per $\mathrm{h}$ ), $0.05 \mathrm{ml} 0.01 \mathrm{M} o$-phenanthroline, and $0.35 \mathrm{ml}$ barbitalsaline buffer at $37^{\circ} \mathrm{C}$ in $12 \times 75-\mathrm{mm}$ polystyrene tubes. After $10 \mathrm{~min}$, suitable portions were tested as described above.

further purification was possible upon columns of SPSephadex C-50, a cationic resin. Preliminary gel filtration studies suggest a molecular weight of about 160,000 . Batch fractionation of small amounts of plasma allowed ready demonstration of corrective activity in eluates of normal plasma, whereas a similar fraction of the patient's plasma lacked this property. Additional delineation of the properties of this agent has not yet been possible.

Under certain conditions, surface contact shortens the Thrombotest time of human plasmas other than those deficient in HF, Fletcher factor, or Factor VII (18, 24). When the patient's plasma was incubated with kaolin at $0^{\circ} \mathrm{C}$ for $4 \mathrm{~h}$, the Thrombotest time did not shorten, whereas that of equal mixtures of his plasma and plasmas deficient in HF or Fletcher factor shortened significantly, from 43 to 25 and from 40 to $24 \mathrm{~s}$, respectively. Thus, the patient's plasma seemed deficient in an agent other than HF, Fletcher factor, or Factor VII, required for this phenomenon.

Studies on generation of kinins and esterolytic activity in Fitzgerald trait. Kinin-like agents inducing con- traction of the estrous rat uterus evolve when normal plasma is incubated with ellagic acid $(10 \mu \mathrm{M})$, an activator of $\mathrm{HF}$, a property lacking in plasmas deficient in $\mathrm{HF}$ or Fletcher factor. Similarly, generation of kinin-like agents was not observed in the patient's plasma, incubated with ellagic acid, but was found in equal mixtures of the patient's plasma and either HFdeficient or Fletcher trait plasma (Table II). The patient's plasma contained diminished amounts of Fletcher factor (see above); not surprisingly, kinin generation in an equal mixture of the patient's and Fletcher trait plasmas was detectable, but was less than normal.

Kinins evolve in normal or HF-deficient plasma incubated with $\mathrm{HF}$ fragments, but not in similarly treated Fletcher trait plasma (11). Kinin-like agents could not be detected in the patient's plasma upon incubation with $\mathrm{HF}$ fragments, a defect corrected by adding an equal volume of Fletcher trait plasma (Table II).

Addition of partially purified plasma kallikrein induced kinin generation in Fletcher trait plasma, but not in the patient's plasma. This was not due to an inhibitor since kinins generated in an equal mixture of the pa- 


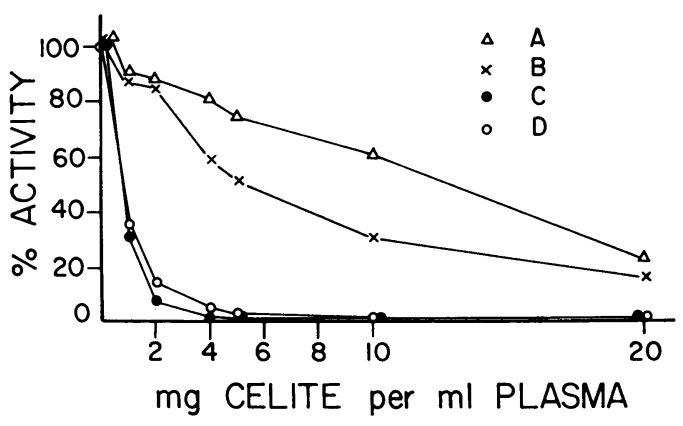

FIGURE 1 Effect of Celite adsorption upon various clotting factor activities. Normal citrated plasma was mixed with varying amounts of Celite 512 in $12 \times 75-\mathrm{mm}$ polystyrene tubes at $37^{\circ} \mathrm{C}$ for $10 \mathrm{~min}$. After centrifugation, the supernatant plasma was separated and incubated at $37^{\circ} \mathrm{C}$ for $18 \mathrm{~h}$. The following clotting factor activities were assayed in the incubated supernatant plasma which was free of activated PTA activity: (A) HF, (B) Fitzgerald factor, (C) Fletcher factor, and (D) PTA. The results were expressed as percentage of activity left in the plasma relative to that of the plasma treated similarly without Celite.

tient's and Fletcher trait plasmas upon addition of kallikrein, but not in an equal mixture of the patient's plasma and barbital-saline buffer (Table II). The patient's plasma contained adequate amounts of kininogen, demonstrated by incubation of boiled plasma with trypsin; the concentration of kininogen was estimated to be about half that of pooled normal plasma. The rate of inactivation of synthetic bradykinin was approximately the same in the patient's and in normal plasma, demonstrating the absence of excessive kininase activity.

When normal plasma is incubated with kaolin, esterolytic activity generates rapidly (25); this property, de-

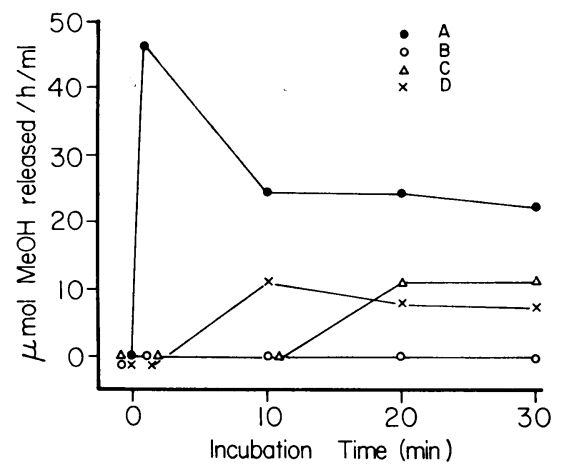

FIgURe 2 Kaolin activation of plasma TAME esterase activity in (A) normal plasma, (B) Fitzgerald trait plasma, (C) Fletcher trait plasma, and (D) 1:1 mixture of Fitzgerald trait and Fletcher trait plasma. $0.1 \mathrm{ml}$ test plasma was incubated with $0.1 \mathrm{ml}$ kaolin suspension $(10 \mathrm{mg} / \mathrm{ml} 0.1$ $M$ sodium phosphate buffer, $\mathrm{pH} 7.5$ in $0.15 \mathrm{M} \mathrm{NaCl}$ ) in $12 \times 75-\mathrm{mm}$ polystyrene tubes at $25^{\circ} \mathrm{C}$. At intervals, $2 \mathrm{ml}$ of ice-cold $0.05 \mathrm{M}$ TAME was added to the tubes and esterase activity was measured as described in the Methods section.
TABLE III

Kaolin-Induced Generation of Fibrinolytic Activity of Fitzgerald Trait

\begin{tabular}{lc}
\hline \multicolumn{1}{c}{ Test plasma } & Lysis time \\
\hline & $\min$ \\
Fitzgerald trait & $>120$ \\
Hageman trait & $>120$ \\
Fletcher trait & $>120$ \\
$50 \%$ Fitzgerald $+50 \%$ Hageman trait & 8 \\
$50 \%$ Fitzgerald $+50 \%$ Fletcher trait & 8 \\
Normal & 7 \\
\hline
\end{tabular}

$0.5 \mathrm{ml}$ test plasma, $0.25 \mathrm{ml}$ kaolin $(8 \mathrm{mg} / \mathrm{ml})$, and $9.25 \mathrm{ml}$ $0.01 \mathrm{M}$ sodium acetate buffer ( $\mathrm{pH} 4.8$ ) were incubated together in $17 \times 100-\mathrm{mm}$ polystyrene tubes at $37^{\circ} \mathrm{C}$ for $60 \mathrm{~min}$. After centrifugation, the supernatant solution was discarded and the euglobulin precipitate, containing kaolin, was resuspended in $0.5 \mathrm{ml}$ barbital-saline buffer. $0.2-\mathrm{ml}$ portions of the euglobulin-kaolin suspension were mixed with $0.1 \mathrm{ml}$ bovine fibrinogen $(3 \mathrm{mg} / \mathrm{ml})$ and $0.1 \mathrm{ml}$ bovine thrombin (Parke Davis \& Co., Detroit, Mich.) in $10 \times 75-\mathrm{mm}$ polystyrene tubes. The clot lysis time was measured at $37^{\circ} \mathrm{C}$.

fective in HF-deficient and Fletcher factor-deficient plasmas $(11,15)$, has been ascribed to generation of a plasma kallikrein (15). Evolution of esterolytic activity, tested upon TAME, was deficient in the patient's plasma and was only partially corrected by addition of Fletcher trait plasma, presumably because the patient's plasma contained diminished amounts of prekallikrein and Fletcher trait plasma contained none (Fig. 2).

Studies on generation of fibrinolytic activity in Fitzgerald trait. Fibrinolytic activity generates in normal diluted and acidified plasma incubated with kaolin (26) an effect mediated by an agent called HF-cofactor (23) or plasminogen activator (27). Generation of fibrinolytic activity in the patient's plasma was deficient, an abnormality also observed in HF-deficient and Fletcher factor-deficient plasmas (Table III). Functional and immunodiffusion assays showed that defective generation of fibrinolytic activity in the patient's plasma was not due to deficiency of plasminogen or to increased amounts of plasmin inhibitors or fibrinogen. Defective generation of fibrinolytic activity was corrected by addition of equal volumes of HF-deficient or Fletcher factor-deficient plasma, which reduced the lysis time of fibrin clots from $>120 \mathrm{~min}$ for each plasma alone to 8 min. Unilike Fletcher trait plasma (10), the clot lysis time of the patient's plasma was not significantly reduced by prolonged surface contact before acidification and dilution.

Ogston, Ogston, Ratnoff, and Forbes (23) demonstrated that $\mathrm{HF}$-induced fibrinolysis required the presence not only of HF-cofactor but also of an ill-defined additional agent. This substance, previously found in 
TABLE IV

Effect-of Ellagic Acid on the Development of Permeability-Enhancing Activity in Fitzgerald Trait Plasma

\begin{tabular}{|c|c|c|c|}
\hline \multirow[b]{2}{*}{ Plasma (diluted $1 / 100$ ) } & \multirow[b]{2}{*}{ Diluent } & \multicolumn{2}{|c|}{$\begin{array}{l}\text { Permeability-enhancing } \\
\text { activity }\end{array}$} \\
\hline & & $0 \mathrm{~min}$ & $12 \mathrm{~min}$ \\
\hline & & $m m$ & $m m$ \\
\hline Normal & Buffer & 2.7 & 2.8 \\
\hline Normal & Ellagic acid & 2.8 & 6.3 \\
\hline Hageman trait & Ellagic acid & 2.4 & 2.4 \\
\hline Fletcher trait & Ellagic acid & 3.3 & 1.6 \\
\hline Fitzgerald trait & Ellagic acid & 2.8 & 1.7 \\
\hline $50 \%$ Fitzgerald trait $+50 \%$ Hageman trait & Ellagic acid & 3.1 & 5.4 \\
\hline $50 \%$ Fitzgerald trait $+50 \%$ Fletcher trait & Ellagic acid & 2.5 & 5.1 \\
\hline Buffer & Ellagic acid & - & 3.2 \\
\hline
\end{tabular}

$0.05 \mathrm{ml}$ plasma was diluted with $4.95 \mathrm{ml} 0.0001 \mathrm{M}$ ellagic acid or with barbital-saline buffer in $13 \times 100$-mm silicone-coated glass tubes. Each tube was incubated at $37^{\circ} \mathrm{C}$ and, at the time indicated, $0.1-\mathrm{ml}$ samples were injected intracutaneously into each of four guinea pigs. The permeability-enhancing activity was measured as described in the Methods sections as the mean diameter of blued spots.

Fletcher trait plasma (10), was also present in the patient's plasma.

Studies on the generation of PF/Dil in Fitzgerald trait. Normal plasma, diluted and incubated with ellagic acid, enhances vascular permeability in guinea pig skin (28). This property, designated PF/Dil, does not appear in similarly treated $\mathrm{HF}$-deficient (28) or Fletcher factor-deficient $(2,10)$ plasmas, nor did it in the patient's plasma, whereas PF/Dil developed in an equal mixture of the patient's plasma and either of the other two (Table IV). The addition of ellagic acidactivated $\mathrm{HF}$ or $\mathrm{HF}$ fragments generated $\mathrm{PF} / \mathrm{Dil}$ in Hageman trait plasma, but not in the patient's plasma (Table V).

Family studies in Fitzgerald trait. We do not know the range of concentration in normal plasma of the agent apparently deficient in the patient's plasma, but that of the patient's sole surviving sister was $40 \%$ that of a pool of normal plasma, and that of his only son was $70 \%$. The titer was $120 \%$ of the pooled plasma in an individual with Fletcher trait, and ranged from 52 to $105 \%$ in four subjects with Hageman trait and from 80 to $130 \%$ in four subjects with PTA deficiency.

\section{DISCUSSION}

When human plasma is exposed to glass or similar negatively charged agents, a series of reactions ensues consequent upon the activation of $\mathrm{HF}$. These reactions include $(a)$ enhancement of clotting via activation of PTA and augmentation of the clot-promoting properties of factor VII, (b) elaboration of kinins via activation of Fletcher factor (a plasma prekallikrein), (c) induction of fibrinolysis via activation of $\mathrm{HF}$ cofactor, (d) enhancement of vascular permeability upon dilution of plasma, and (e) chemotaxis. Evidence has accumulated that Fletcher factor, activated by $\mathrm{HF}$, either mediates or intensifies these various reactions $(1,2)$.

In the experiments reported, the prolonged activated PTT in the plasma of an asymptomatic man, Allen Fitzgerald, was related to the deficiency of an agent not identified with known clotting factors. The defect, localized to a step after activation of $\mathrm{HF}$ and Fletcher factor and before participation of activated PTA, was corrected by human plasma deficient in HF, PTA, or Fletcher factor, or by cetacean plasma, deficient in $\mathrm{HF}$

\section{TABLE V}

Effect of Ellagic Acid-Activated HF or HF Fragments on the Development of Permeability-Enhancing Activity

\begin{tabular}{llcc}
\hline & & $\begin{array}{c}\text { Permeability-enhancing } \\
\text { activity }\end{array}$ \\
\cline { 3 - 4 } Plasma (diluted 1/100) & Diluent & 0 min & $12 \mathrm{~min}$ \\
\hline & & $\mathrm{mm}$ & $\mathrm{mm}$ \\
Normal & Ellagic acid-HF & 5.6 & 6.3 \\
Hageman trait & Ellagic acid-HF & 5.8 & 7.6 \\
Fitzgerald trait & Ellagic acid-HF & 2.9 & 4.6 \\
Buffer & Ellagic acid-HF & - & 4.0 \\
Hageman trait & HF fragments & 2.3 & 5.3 \\
Fletcher trait & HF fragments & 1.3 & 2.0 \\
Fitzgerald trait & HF fragments & 1.1 & 2.0 \\
Buffer & HF fragments & 2.6 & - \\
\hline
\end{tabular}

$0.02 \mathrm{ml}$ plasma was diluted with $2 \mathrm{ml}$ ellagic acid- $\mathrm{HF}(0.2 \mu \mathrm{g} \mathrm{HF} / \mathrm{ml}$ $0.0001 \mathrm{M}$ ellagic acid) or HF fragments ( $0.05 \mu \mathrm{gF}$ fragments $/ \mathrm{ml}$ barbitalsaline buffer) in $13 \times 100-\mathrm{mm}$ silicone-coated glass tubes. Each tube was Incubated at $37^{\circ} \mathrm{C}$, and, at the times indicated, $0.1-\mathrm{ml}$ portions were injected intracutaneousiy into each of four guinea pigs. The permeabilityenhancing activity was measured as described in the Methods section. 
and Fletcher factor, but not by certain fowl plasmas. The shortening of the Thrombotest time in cold-stored plasma, the generation of kinins, esterolytic activity resembling a plasma kallikrein, kaolin-induced fibrinolytic activity, and the plasma property designated PF/ Dil were all impaired.

These observations are of particular interest because previous studies have demonstrated that the generation of activated PTA (4) and of fibrinolytic activity (23) and the augmentation of factor VII activity, as measured by shortening of the Thrombotest time in coldstored plasma (24), all require not only the presence of activated $\mathrm{HF}$ and Fletcher factor, but other, not yet unidentified agents. It is not yet clear whether the agent deficient in Fitzgerald trait plasma is identical with one or another of these agents, but this plasma appeared to contain adequate amounts of one additional agent required for fibrinolysis described by Ogston et al. (23).

The several defects in the patient's plasma were corrected by addition of $\mathrm{HF}$-deficient or Fletcher factordeficient plasma. Addition of Fletcher trait plasma was less effective in kinin-generating or esterolytic systems than Hageman trait plasma because the patient's plasma contained only $10-15 \%$ Fletcher factor.

Failure of purified plasma kallikrein to correct the clotting defect and to induce kinin-like properties in the patient's plasma fortified the view that the deficient agent is not Fletcher factor. Separation from the precursor of HF-cofactor is less secure because the identity of this agent is disputed, but this latter substance, like plasma prekallikrein and PTA, does not adsorb to anionic exchange resins. In contrast, a crude fraction that corrected the clotting defect could be prepared from normal plasma by adsorption and elution from anionic exchange resins. A similar fraction of the patient's plasma was deficient in this property. HF, too, is adsorbed to anionic exchange resins (29), but the corrective fraction required higher salt concentrations for elution than $\mathrm{HF}$, it could readily be prepared from $\mathrm{HF}$ deficient plasma, and it probably has a higher molecular weight.

The mode of action of the agent deficient in the patient's plasma is not yet clear. Experiments demonstrating that activated HF and kallikrein did not shorten the clotting time of the patient's plasma nor induce kinin generation suggest that it may participate in reactions subsequent to the activation of prekallikrein by activated $\mathrm{HF}$ or HF fragments. No evidence is yet available to suggest that the newly recognized agent (or agents) is activated from a precursor state during the clotting process. Nor do we know if it acts by inducing a further change in kallikrein, by altering the various proenzymes participating in surface-mediated reactions, or by serving as a necessary cofactor in the several reac- tions studied, including activation of PTA, augmentation of the action of factor VII, surface-induced fibrinolysis, generation of plasma esterolytic activity, kinin generation, and elaboration of the property described as PF/Dil.

These experiments, admittedly incomplete, support the view that the agent deficient in the patient's plasma is not identified with other recognized agents. Tentatively then, it can be called Fitzgerald factor until its nature is defined. In addition to $\mathrm{HF}$ and Fletcher factor, Fitzgerald factor appears to participate in surface-mediated biological reactions. Whether Fitzgerald factor has been described by earlier investigators is not known.

Note added in proof. Since this paper was accepted for publication, two additional cases with a clotting defect identical to that of Fitzgerald trait have been detected. Donaldson, Glueck, and Miller (30) will report that the abnormality appears to be inherited as an autosomal recessive trait. The concentration of kininogen in their patient's plasma was less than $1 \%$ of normal. Wuepper, Miller, and Lacombe (31) have described a patient, said to have Flaujeac factor deficiency, whose abnormality was corrected by fractions of plasma containing high molecular weight (HMW) kininogen. Our own patient is deficient in HMW, but not low molecular weight kininogen, and we have been unable to separate fractions with Fitzgerald factor activity from those containing HMW kininogen despite further purification.

\section{ACKNOWLEDGMENTS}

We thank Dr. J. Pensky for assaying Cī inactivator and Ms. Janet Shlaes for providing invaluable technical help.

This study was supported in part by Grant HL 01661 from the National Heart and Lung Institute, the National Institutes of Health, U. S. Public Health Service, and in part by grants from the American Heart Association.

\section{REFERENCES}

1. Hathaway, W. E., L. P. Belhasen, and H. S. Hathaway. 1965. Evidence for a new plasma thromboplastin factor. I. Case report, coagulation studies, and physicochemical properties. Blood J. Hematol. 26: 521-532.

2. Wuepper, K. D. 1972. Biochemistry and biology of components of the plasma kinin-forming system. In Inflammation: Mechanisms and Controls. I. H. Lepow and P. A. Ward, editors. Academic Press, Inc., New York. 93-117.

3. Ratnoff, O. D., E. W. Davie, and D. L. Mallett. 1961. Studies on the action of Hageman factor. Evidence that activated Hageman factor in turn activates plasma thromboplastin antecedent. J. Clin. Invest. 40: 803-819.

4. Schiffman, S., and P. Lee. 1974. Preparation, characterization, and activation of a highly purified factor XI: evidence that a hitherto unrecognized plasma activity participates in the interaction of factors XI and XII. Br. J. Haematol. 27 : 101-114.

5. Waldmann, R., and J. Abraham. 1974. Fitzgerald factor: a heretofore unrecognized coagulation factor. Blood J. Hematol. 44 : 934. (Abstr.) 
6. Saito, H., O. D. Ratnoff, R. Waldmann, and J. Abraham. 1974. Impaired Hageman factor (factor XII)mediated reactions in "Fitzgerald trait." Blood J. Hematol. 44 : 934. (Abstr.)

7. Colman, R. W., A. Bagdasarian, R. C. Talamo, and A. P. Kaplan. 1974. Proceedings of the International Conference on Chemistry and Biology of the KallikreinKinin System in Health and Disease. In press.

8. Saito, H., O. D. Ratnoff, J. S. Marshall, and J. Pensky. 1973. Partial purification of plasma thromboplastin antecedent (factor XI) and its activation by trypsin. $J$. Clin. Invest. 52 : 850-861.

9. Saito, H., G. Goldsmith, and O. D. Ratnoff. 1974. Fletcher factor activity in various species. Proc. Soc. Exp. Biol. Med. 147: 519-523.

10. Saito, H., O. D. Ratnoff, and V. H. Donaldson. 1974. Defective activation of clotting, fibrinolysis, and permeability-enhancing systems in human Fletcher trait plasma. Circ. Res. 34: 641-651.

11. Donaldson, V. H., H. Saito, and O. D. Ratnoff. 1974. Defective esterase and kinin-forming activity in human Fletcher trait plasma: a fraction rich in kallikrein-like activity. Circ. Res. $34:$ 652-662.

12. Nossel, H. L. 1964. Contact Phase of Blood Coagulation. F. A. Davis Company, Philadelphia. 23-24.

13. Saito, H., O. D. Ratnoff, and J. Pensky. 1974. Radioimmunoassay of human Hageman factor ( $\mathrm{HF}$, factor XII). Fed. Proc. 33: 226. (Abstr.)

14. Zimmerman, T. S., O. D. Ratnoff, and A. E. Powell. 1971. Immunologic differentiation of classic hemophilia (factor VIII deficiency) and von Willebrand's disease. J. Clin. Invest. 50: 244-254.

15. Colman, R. W., J. W. Mason, and S. Sherry. 1969. Kallikreinogen-kallikrein enzyme system of human plasma: assay of component and observation in disease states. Ann. Intern. Med. 71: 763-773.

16. Levy, L. R., and I. H. Lepow. 1959. Assay and properties of serum inhibitor of C1-esterase. Proc. Soc. Exp. Biol. Med. 101: 608-611.

17. Miles, A. A., and D. L. Wilhelm. 1965. Enzyme-like globulins from serum reproducing the vascular phenomenon of inflammation. I. Activable permeability factor and its inhibitor in guinea-pig serum. Br.J. Exp. Pathol. 36: 71-81.

18. Gjønnaess, H. 1972. Cold promoted activation of factor VII. IV. Relation to the coagulation system. Thromb. Diath. Haemorrh. 28: 194-205.

19. DeJalon, P. G., M. M. Bayo Bayo, and M. G. DeJalon.
1945. Sensible y nuevo metods de valorecion de adrendina en utero osseaus de Rata. Farmacoterap. Actual (Madrid). 2: 313.

20. Davies, G. E., G. Holman, T. P. Johnston, and J. S. Lowe. 1966. Studies on kallikrein: failure of some antiinflammatory drugs to affect release of kinin. Br. J. Pharmacol. Chemother. 28: 212-217.

21. Diniz, C. R., and I. V. Carvalho. 1963. A micromethod for determination of bradykininogen under several conditions. Ann. N. Y. Acad. Sci. 104 : 77-89.

22. Melmon, K. L., M. J. Cline, T. Hughes, and A. S. Nies. 1968. Kinins: possible mediators of neonatal circulatory changes in man. J. Clin. Invest. $47: 1295-1302$.

23. Ogston, D., C. M. Ogston, O. D. Ratnoff, and C. D. Forbes. 1969. Studies on a complex mechanism for the activation of plasminogen by kaolin and by chloroform: participation of Hageman factor and additional cofactors. J. Clin. Invest. 48: 1786-1801.

24. Saito, H., and O. D. Ratnoff. 1975. Alteration of factor VII activity by activated Fletcher factor (a plasma kallikrein): a potential link between the intrinsic and extrinsic blood clotting systems. J. Lab. Clin. Med. 85: 405-415.

25. Eisen, V. 1963. Kinin formation and fibrinolysis in human plasma. J. Physiol. (Lond.). 166: 514-529.

26. Niewiarowski, S., and O. Prou-Wartelle. 1959. Role due facteur contact (facteur Hageman) dans la fibrinolyse. Thromb. Diath. Haemorrh. 3: 593-603.

27. Kaplan, A. P., and K. F. Austen. 1972. Fibrinolytic pathway of human plasma: isolation and characterization of the plasminogen proactivator. J. Exp. Med. 136: 1378-1393.

28. Ratnoff, O. D., and A. A. Miles. 1964. Induction of permeability-increasing activity in human plasma by activated Hageman factor. Br. J. Exp. Pathol. 45: 328345.

29. Ratnoff, O. D., and E. W. Davie. 1962. The purification of activated Hageman factor (activated factor XII). Biochemistry. 1 : 967-974.

30. Donaldson, V. H., H. I. Glueck, and M. A. Miller. 1975. Kininogen deficiency and defective surface activation of blood coagulation and fibrinolysis in a kindred with Fitzgerald trait. Proceedings of 5th Congress of the International Society on Thrombosis and Haemostasis. In press.

31. Wuepper, K. D., D. R. Miller, and M. J. Lacombe. 1975. Flaujeac trait: deficiency of kininogen in man. Fed. Proc. 34: 859. (Abstr.) 